\title{
A compact, high-purity source of HONO validated by Fourier transform infrared and thermal-dissociation cavity ring-down spectroscopy
}

\author{
Nicholas J. Gingerysty and Hans D. Osthoff \\ Department of Chemistry, University of Calgary, 2500 University Drive N.W., Calgary, Alberta, Canada T2N 1N4
}

Correspondence: Hans D. Osthoff (hosthoff@ucalgary.ca)

Received: 19 March 2020 - Discussion started: 23 March 2020

Revised: 29 June 2020 - Accepted: 2 July 2020 - Published: 5 August 2020

\begin{abstract}
A well-characterized source of nitrous acid vapour (HONO) is essential for accurate ambient air measurements by instruments requiring external calibration. In this work, a compact HONO source is described in which gas streams containing dilute concentrations of HONO are generated by flowing hydrochloric acid $(\mathrm{HCl})$ vapour emanating from a permeation tube over continuously agitated dry sodium nitrite $\left(\mathrm{NaNO}_{2}\right)$ heated to $50^{\circ} \mathrm{C}$. Mixing ratios of $\mathrm{HONO}$ and potential by-products including $\mathrm{NO}, \mathrm{NO}_{2}$, and nitrosyl chloride (CINO) were quantified by Fourier transform infrared (FTIR) and thermal-dissociation cavity ring-down spectroscopy (TD-CRDS). A key parameter is the concentration of $\mathrm{HCl}$, which needs to be kept small $(<4 \mathrm{ppmv})$ to avoid CINO formation. The source produces gas streams containing HONO in air in $>95 \%$ purity relative to other nitrogen oxides. The source output is rapidly tuneable and stabilizes within $90 \mathrm{~min}$. Combined with its small size and portability, this source is highly suitable for calibration of HONO instruments in the field.
\end{abstract}

\section{Introduction}

The generation of nitrous acid vapour $\left(\mathrm{HONO}_{(\mathrm{g})}\right)$ free of other nitrogen oxides has been a long-standing challenge to atmospheric chemists (Table 1). Such sources are needed in kinetic studies, for absorption cross-section measurements, and for the calibration of field instruments. Nitrous acid is not suitable for permeation devices since HONO is difficult to prepare in low concentration and in high purity and disproportionates to nitric oxide and nitrogen dioxide via equi- librium (1).

$\mathrm{NO}_{(\mathrm{g})}+\mathrm{NO}_{2(\mathrm{~g})}+\mathrm{H}_{2} \mathrm{O}_{(\mathrm{g})} \rightleftharpoons 2 \mathrm{HONO}_{(\mathrm{g})}$

In fact, early experiments relied on the $\mathrm{NO}, \mathrm{NO}_{2}$, and $\mathrm{H}_{2} \mathrm{O}$ vapour equilibrium to form HONO in situ (King and Moule, 1962; Cox, 1974; Stockwell and Calvert, 1978).

Cox and Derwent prepared HONO vapours in $\sim 50 \%$ purity by flowing nitrogen over an aqueous solution containing $0.1 \mathrm{M}$ sodium nitrite with $1.4 \%-2.5 \%$ sulfuric acid (Cox and Derwent, 1976).

$$
\mathrm{H}_{2} \mathrm{SO}_{4(\mathrm{aq})}+2 \mathrm{NaNO}_{2_{(\mathrm{aq})}} \rightarrow 2 \mathrm{HONO}_{(\mathrm{g})}+2 \mathrm{NaHSO}_{4}(\mathrm{aq})
$$

Braman and de la Cantera sublimed oxalic acid onto solid sodium nitrite and were able to produce gas streams in $>50 \%$ and up to $90 \%$ purity as long as water was present (Braman and De la Cantera, 1986).

$\mathrm{H}_{2} \mathrm{C}_{2} \mathrm{O}_{4(\mathrm{~g})}+\mathrm{NaNO}_{2(\mathrm{~s})} \stackrel{\mathrm{H}_{2} \mathrm{O}}{\longrightarrow} \mathrm{HONO}_{(\mathrm{g})}+\mathrm{NaHC}_{2} \mathrm{O}_{4(\mathrm{~s})}$

Subsequent refinements included a flow reactor design in solutions of sulfuric acid and sodium nitrite were dynamically mixed, producing a stable output in $>90 \%$ purity (Taira and Kanda, 1990).

Febo et al. (1995) developed a method in which gas-phase hydrochloric acid emitted from a permeation device was quantitatively reacted in a humidified gas stream with solid sodium nitrite, producing a stable and highly pure $(>99.5 \%)$ HONO output.

$\mathrm{HCl}_{(\mathrm{g})}+\mathrm{NaNO}_{2(\mathrm{~s})} \stackrel{\mathrm{H}_{2} \mathrm{O}}{\longrightarrow} \mathrm{HONO}_{(\mathrm{g})}+\mathrm{NaCl}_{(\mathrm{s})}$ 
Table 1. Selected HONO generation systems described in the literature. CAPS: cavity-attenuated phase-shift spectroscopy. n/d: not disclosed.

\begin{tabular}{|c|c|c|c|c|}
\hline Reference & Method & Analytical method & Result & Notes \\
\hline $\begin{array}{l}\text { King and Moule (1962), } \\
\text { Stockwell and Calvert } \\
(1978)\end{array}$ & (R1) & UV absorption & $\begin{array}{l}\text { Mixture of } \mathrm{NO}, \mathrm{NO}_{2} \\
\text { and HONO }\end{array}$ & Equilibration of Reaction (R1) \\
\hline Cox (1974) & (R1) & $\begin{array}{l}\mathrm{NO} \text { and "total } \mathrm{NO}_{x} \text { " } \\
\mathrm{CL} ; \mathrm{HONO} \text { scrubbed w/ } \\
\mathrm{NaOH}(0.1 \mathrm{~N})\end{array}$ & $\begin{array}{l}\text { Mixture of } \mathrm{NO}, \mathrm{NO}_{2} \\
\text { and HONO }\end{array}$ & Equilibration of Reaction (R1) \\
\hline Cox and Derwent (1976) & (R2) & $\begin{array}{l}\mathrm{NO} \text { and "total } \mathrm{NO}_{x} \text { " } \\
\mathrm{CL} ; \mathrm{HONO} \text { scrubbed w/ } \\
\mathrm{NaOH}(0.1 \mathrm{~N})\end{array}$ & $\begin{array}{l}\text { Mixture of } \mathrm{NO}, \mathrm{NO}_{2} \\
\text { and } \sim 50 \% \mathrm{HONO}\end{array}$ & $\begin{array}{l}\text { Volatilization of "nitrous } \\
\text { fumes" from solution of } \\
\text { sulfuric acid and sodium nitrite }\end{array}$ \\
\hline $\begin{array}{l}\text { Braman and De la Cantera } \\
\text { (1986) }\end{array}$ & (R3) & $\begin{array}{l}\mathrm{NO} / \mathrm{NO}_{y} \mathrm{CL} \text { analyser (heated } \\
\mathrm{Au} \text { tube) }\end{array}$ & $\begin{array}{l}\text { Mixture of } \mathrm{NO}, \mathrm{NO}_{2} \\
\text { and } 50 \%-90 \% \mathrm{HONO}\end{array}$ & $\begin{array}{l}\text { Sublimation of oxalic acid on } \\
\text { sodium nitrite }\end{array}$ \\
\hline Taira and Kanda (1990) & (R2) & $\begin{array}{l}\mathrm{NO} / \mathrm{NO}_{y} \mathrm{CL} \text { analyser (carbon } \\
\text { converter); } \mathrm{HONO} \text { collected on } \\
\mathrm{Na}_{2} \mathrm{CO}_{3} \text { filters and analysed } \\
\text { by } \\
\text { IC }\end{array}$ & $\begin{array}{l}\text { Mixture containing } \\
2 \%-3 \% \mathrm{NO} \text { and } \\
4 \%-6 \% \mathrm{NO}_{2}\end{array}$ & $\begin{array}{l}\text { Volatilization of HONO from } \\
\text { dynamically mixed sodium } \\
\text { nitrite and sulfuric acid solution }\end{array}$ \\
\hline $\begin{array}{l}\text { Febo et al. (1995), Stutz et } \\
\text { al. (2000) }\end{array}$ & (R4) & DOAS $\left(\mathrm{NO}_{2}, \mathrm{HONO}\right) ; \mathrm{NO} \mathrm{CL}$ & $>99.5 \%$ purity & $\begin{array}{l}1 \mathrm{~L} \text { bath, } 2 \mathrm{~m} \text { reverse diffusion } \\
\text { tube, heated stirring reactor }\end{array}$ \\
\hline Brust et al. (2000) & (R4) & $\begin{array}{l}\text { FTIR }\left(\mathrm{NO}_{2}, \mathrm{HONO}\right), \mathrm{IC} \\
(\mathrm{HONO})\end{array}$ & $\begin{array}{l}\text { Up to } 22 \mathrm{ppm} \\
<2 \% \mathrm{NO}_{2}\end{array}$ & $\begin{array}{l}20 \mathrm{~cm} \text { reverse diffusion, heated } \\
\text { reactor }\end{array}$ \\
\hline Schiller et al. (2001) & (R4) & $\begin{array}{l}\text { TLDAS (HONO), FTIR } \\
\text { (HONO) } \\
\text { IC of KOH solutions }\end{array}$ & $\mathrm{n} / \mathrm{d}$ & $\begin{array}{l}\text { Bubbled } \mathrm{N}_{2} \text { through } 0.5 \mathrm{M} \mathrm{HCl} \\
\text { followed by reaction with solid } \\
\text { sodium nitrite }\end{array}$ \\
\hline Perez et al. (2007) & (R4) & TD-CL, TD-LIF & Observed CINO & Same setup as Febo et al. (1995) \\
\hline Perez et al. (2007) & (R2) & TD-CL, TD-LIF & $>95 \%$ & $\begin{array}{l}\text { Flowed } \mathrm{H}_{2} \mathrm{SO}_{4} \text { aerosol over } \\
\mathrm{NaNO}_{2} \text { sandwiched between } \\
\text { paper filters }\end{array}$ \\
\hline Roberts et al. (2010) & (R4) & IBBCEAS, $\mathrm{NO}_{y}$-CL, CIMS & $>95 \%$ & $\begin{array}{l}\mathrm{HCl} \text { gas cylinder }(10 \mathrm{ppmv}) \text { and } \\
\mathrm{NaNO}_{2} \text { reactor tube }\end{array}$ \\
\hline Ren et al. (2010) & (R4) & LOPAP, $\mathrm{NO}_{y}$-CL, CIMS & $\mathrm{n} / \mathrm{d}$ & $\begin{array}{l}\text { Reverse diffusion tube, high } \\
{[\mathrm{HCl}](9-12 \mathrm{M}) \text {, tubing thick- }} \\
\text { ness not described }\end{array}$ \\
\hline Reed et al. (2016) & (R2) & $\begin{array}{l}\text { Differential photolysis NO-CL; } \\
\mathrm{NO}_{2} \text { CAPS; FTIR }\end{array}$ & $\begin{array}{l}\mathrm{HONO}(70.4 \% \\
<50 \mathrm{ppbv}) \\
\mathrm{NO}(15 \%) \\
\mathrm{NO}_{2}(12.8 \%) \\
\mathrm{HNO}_{3}(1.3 \%)\end{array}$ & $\begin{array}{l}\text { Perm tube filled with } 37 \% \mathrm{HCl} \\
\text { placed in oven with } \mathrm{NaNO}_{2} \\
\text { salt; flushed at } 1.5 \mathrm{slpm} ; \\
<50 \text { ppbv }\end{array}$ \\
\hline
\end{tabular}

The output of sources based on Reaction (R4) has been characterized by differential optical absorption spectroscopy (DOAS) (Febo et al., 1995; Stutz et al., 2000), Fourier transform infrared (FTIR) spectroscopy (Brust et al., 2000; Schiller et al., 2001), tuneable diode laser absorption spectroscopy (TLDAS) (Schiller et al., 2001), incoherent cavityenhanced absorption spectroscopy (IBBCEAS) (Roberts et al., 2010), and long-path optical absorption photometry (LOPAP) (Ren et al., 2010). Stutz et al. (2000) noted that concentrations of HONO should be kept low (< $10^{14}$ molecules $\mathrm{cm}^{-3} ; \sim 4 \mathrm{ppmv}$ ) to avoid disproportionation of HONO via Reaction (R1).

Perez et al. (2007) examined a source based on the design by Febo et al. (1995) using thermal-dissociation chemiluminescence (TD-CL) detection of $\mathrm{NO}$ and reported that their source co-emitted nitrosyl chloride (ClNO); they opted to generate $\mathrm{HONO}$ from reaction of $\mathrm{H}_{2} \mathrm{SO}_{4}$ aerosol with $\mathrm{NaNO}_{2}$ (s) instead. In contrast, Roberts et al. (2010) observed 
little or no production of $\mathrm{CINO}(<4.5 \%)$ and quantitative conversion of $\mathrm{HCl}$ to $\mathrm{HONO}$, at odds with Perez et al. (2007) but in agreement with the original work by Febo et al. (1995). As far as we know, this inconsistency is unexplained to date.

As part of our development of an IBBCEAS for HONO measurement, our lab recently constructed a HONO source using an aqueous solution of $\mathrm{NaNO}_{2}$ buffered with oxalate to pH 3.74 (Jordan and Osthoff, 2020). This source generated HONO in trace amounts suitable to our needs but co-emitted $\mathrm{NO}$ and $\mathrm{NO}_{2}$ in similar ratios to those reported by Braman and De la Cantera (1986). Furthermore, this type of source could not be turned off (i.e., had to remain under continuous $\mathrm{N}_{2}$ flow) and required long times to stabilize, motivating us to develop an alternative HONO generation method. Ambient air HONO measurement techniques that need to be externally calibrated often poorly agree with each other (Crilley et al., 2019), further motivating the development of a wellcharacterized, compact, and portable HONO source and improved understanding of conditions needed to suppress formation of undesired side products such as CINO.

In this work, we describe the implementation of a compact, high-purity HONO generation device based on R4 for field deployment and laboratory experiments and characterized its output by FTIR and thermal-dissociation cavity ringdown spectroscopy (TD-CRDS). Conditions to avoid generation of impurities such as ClNO are identified. The performance of this source in comparison to existing methods is discussed.

\section{Materials and methods}

\subsection{Generation of gas streams containing HONO}

A practical challenge is the generation of stable and dilute gas streams containing $\mathrm{HCl}$. Calibration gas cylinders are the most straightforward method to use for this purpose but may require periods of up to $10 \mathrm{~d}$ to stabilize (Roberts et al., 2010). Furthermore, low-concentration $\mathrm{HCl}$ gas cylinders are expensive to source, such that we chose to generate $\mathrm{HCl}$ gas through the use of relatively inexpensive permeation devices.

In the setup by Febo et al. (1995), which was also implemented by Brust et al. (2000), Stutz et al. (2000), and Ren et al. (2010), a gas stream of $\mathrm{N}_{2}$ is passed through Teflon tubing immersed in an $\mathrm{HCl}$ bath. This setup involved a rather large $1 \mathrm{~L}$ vessel containing liquid $\mathrm{HCl}$, which is somewhat impractical and potentially hazardous in a field setting. With portability in mind, we decided to construct a permeation tube containing $\mathrm{HCl}(\mathrm{l})$. The literature does not inform as to suitable tube dimensions, which were determined through trial and error.

Three HONO sources were constructed and evaluated. In the first ("source 1"), a $24 \mathrm{~cm}$ long, polytetrafluoroethylene (PTFE) permeation tube (Chromatographic Specialties C111LE; wall thickness $1.5 \mathrm{~mm}$; outer diameter (o.d.)
$7.8 \mathrm{~mm}$ ) was filled with $2.5 \mathrm{~mL}$ of $37 \% \mathrm{HCl}$ (Sigma-Aldrich) and sealed at both ends with PTFE plugs held in place by stainless steel compression rings. The permeation tube was placed inside a glass chamber (VICI Dynacalibrator Model 120) whose temperature was controlled at $25.0^{\circ} \mathrm{C}$ and which was continuously flushed at a flow rate of $\sim 0.15 \mathrm{~L} \mathrm{~min}^{-1}$ with room air scrubbed using activated charcoal for a period of several days into a fume hood. The use of scrubbed air ensured that the gas stream contained water to maintain efficient HONO production (Schiller et al., 2001). For the experiments shown in this paper, the relative humidity of the diluent gas stream was in the range of $15 \%$ to $35 \%$.

The $\mathrm{HCl}$ output was diluted in a gas stream of $\mathrm{O}_{2}$ $\left(\sim 20 \mathrm{~mL} \mathrm{~min}^{-1}\right)$; this gas stream also served to continuously flush the connecting tubing when not in use. Roughly $1.5 \mathrm{~g}$ of solid $\mathrm{NaNO}_{2}$ was placed inside a $50 \mathrm{~cm}$ long loop of $3 / 16^{\prime \prime}$ $(0.476 \mathrm{~cm})$ inner diameter (i.d.) and $1 / 4^{\prime \prime}(0.635 \mathrm{~cm})$ o.d. fluorinated ethylene propylene (FEP) Teflon tubing downstream from the $\mathrm{HCl}$ addition point. This section could be manually bypassed with a pair of three-way valves (Entegris) to turn HONO production on or off. A Teflon filter (Pall, $2 \mu \mathrm{m}$ pore size and $47 \mathrm{~mm}$ diameter) inside a Teflon filter holder (ColeParmer) was placed downstream of the $\mathrm{NaNO}_{2}$ powder.

In the second source ("source 2"), the $\mathrm{NaNO}_{2}$ was placed in a two-neck, $50 \mathrm{~mL}$ Pyrex round bottom flask which was covered in aluminium foil to prevent photolysis of nitrite and nitrous acid and was externally heated to a temperature of $50^{\circ} \mathrm{C}$ using a water bath and mechanically agitated using a magnetic stir bar as described by Febo et al. (1995). Heating this vessel promotes dissociation of molecular clusters such as $\mathrm{N}_{2} \mathrm{O}_{4}$ and partitioning of wall-adsorbed molecules to the gas phase, which, if present, can drive HONO decomposition on borosilicate glass surfaces (Syomin and Finlayson-Pitts, 2003).

The third source ("optimized source") used the same setup as source 2 , except that a shorter permeation tube (length $6 \mathrm{~cm}$ ) containing $0.35 \mathrm{~mL}$ of $\mathrm{HCl}$ was used. This setup is depicted in Fig. 1. The overall dimensions are $28 \mathrm{~cm} \times 28 \mathrm{~cm} \times 36 \mathrm{~cm}$ and its modular design ensures easy transport to and from the field.

To deliver HONO in atmospheric concentrations (i.e., $<10 \mathrm{ppbv}$ ), a portion of the source output was directed towards waste with the aid of a pump and a needle valve. The output concentration could be rapidly changed (typically by factors between 5 and 200) by adjusting the position of the needle valve. The remaining output was diluted using scrubbed air and directed towards the instruments at a final flow rate slightly larger than the sampling requirement of the instruments.

\subsection{Analysis of HONO source output by FTIR}

Gas streams exiting the HONO sources (prior to dilution) were analysed using an FTIR spectrometer (Bruker Tensor 27) equipped with a liquid nitrogen cooled mercury cad- 


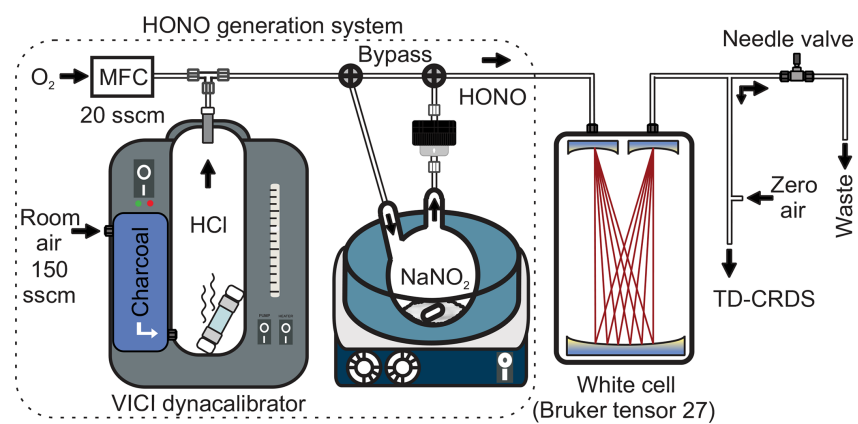

Figure 1. Schematics of the experimental setup. The high-purity HONO generation system is shown on the left (dotted border). MFC: mass flow controller. sccm: standard cubic centimetre per minute.

mium telluride (MCT) detector and a White multi-pass gas cell with a $6.4 \mathrm{~m}$ optical path length and an internal volume of $0.75 \mathrm{~L}$ (Gemini Scientific Instruments, Venus series) in a similar fashion to that described earlier (Taha et al., 2013). Room-temperature spectra were acquired continuously at a time resolution of $30 \mathrm{~s}$. Background spectra were recorded with $\mathrm{HCl}$ inline but with the $\mathrm{NaNO}_{2}$ bypassed, which resulted in the observed spectra showing the change in trace gas concentrations.

Mixing ratios of trace gases were determined from fits (by least squares error minimization over a selected wavelength range) of room-temperature reference spectra from the Pacific Northwest National Laboratory (Sharpe et al., 2004), multiplied by the respective mixing ratios as variables, to the observed spectra. The reference spectra are provided in units of ppmv at atmospheric pressure per meter of optical length, necessitating a correction factor of 6.4 accounting for the actual path length and a pressure correction factor for which the pressure inside the multi-pass cell (which was equal to that of the room) was monitored using a pressure transducer (Omegadyne PX419-015A5V).

The FTIR limits of detection (LODs) are specific to each molecule (due to differing absorption cross sections) and are in the 100 to 300 parts-per-billion (by volume; ppbv; $10^{-9}$ ) range. For example, the $1 \sigma$ precision of $\mathrm{NO}_{2}$ data was \pm 100 ppbv, yielding a $3 \sigma$ LOD of 300 ppbv.

The spectral resolution of the FTIR was $\sim 0.5 \mathrm{~cm}^{-1}$, which does not suffice to fully resolve the absorption lines of $\mathrm{HCl}, \mathrm{H}_{2} \mathrm{O}$, and $\mathrm{NO}$; their FTIR-derived mixing ratios are hence lower limits.

\subsection{Analysis of HONO source output by TD-CRDS}

The (diluted) HONO source output was also analysed using a four-channel TD-CRDS instrument (Odame-Ankrah, 2015). Briefly, mixing ratios of $\mathrm{NO}_{2}$ are quantified by absorption at $405 \mathrm{~nm}$. Ring-down time constants in the absence $\left(\tau_{0}\right)$ and presence $(\tau)$ of $\mathrm{NO}_{2}$ are converted to concentrations $(N)$ using Eq. (2), where $c$ is the speed of light, $\sigma$ is the $\mathrm{NO}_{2}$ ab- sorption cross section, and $R_{L}$ is a correction factor $(\sim 1.2)$ accounting for mirror purge flows (Paul and Osthoff, 2010).

$N=\frac{R_{L}}{c \sigma}\left(\frac{1}{\tau}-\frac{1}{\tau_{0}}\right)$

Concentrations are converted to mixing ratios using the ideal gas law. Other $\mathrm{NO}_{y}$ components are converted to $\mathrm{NO}_{2}$ in separate channels and are quantified by difference.

For this study, the instrument was operated as follows: mixing ratios of $\mathrm{NO}_{2}$ were monitored using a room temperature, $1 / 4^{\prime \prime}(0.64 \mathrm{~cm})$ o.d., and $1 / 8^{\prime \prime}(0.32 \mathrm{~cm})$ i.d. FEP Teflon inlet. Mixing ratios of $\mathrm{NO}_{x}$ were quantified on a second channel with a room temperature Teflon inlet and by adding $\mathrm{O}_{3}$ (mixing ratio after addition of $\sim 3 \mathrm{ppmv}$ ) to titrate $\mathrm{NO}$ to $\mathrm{NO}_{2}$ (Odame-Ankrah, 2015; Fuchs et al., 2009). A third channel was operated with a $1 / 4^{\prime \prime}(0.64 \mathrm{~cm})$ o.d. quartz inlet heated to $600^{\circ} \mathrm{C}$. Ozone was added between the quartz inlet and the CRDS cell to quantify $\mathrm{NO}_{y}$, including $\mathrm{HONO}$ (Jordan and Osthoff, 2020; Wild et al., 2014; Perez et al., 2007). The fourth inlet was operated at $350{ }^{\circ} \mathrm{C}$ and with added $\mathrm{O}_{3}$. This channel quantified $\mathrm{NO}_{x}+\Sigma \mathrm{PAN}+\Sigma \mathrm{AN}+$ $\mathrm{ClNO}+\mathrm{ClNO}_{2}$ and was used as a $\mathrm{HONO}$ reference channel. Each channel sampled at a flow rate of $\sim 0.8 \mathrm{slpm}$ through $\sim 5 \mathrm{~cm}$ short, $1 / 16^{\prime \prime}$ i.d. Teflon flow restrictors placed inline after the heated quartz sections (if existing) and before a $50 \mathrm{~mm}$ Teflon (Pall Teflo, $2 \mu \mathrm{m}$ pore size) housed in a Teflon filter holder (Cole Parmer). The laser pulse repetition rate was $1500 \mathrm{~Hz}$, and 1500 ring-down events were averaged to produce $1 \mathrm{~s}$ data.

\subsection{Field deployment}

The HONO source was utilized during the "Study of nitrogen oxides in winter downwind from oil and gas sands" (SNOWDOGS) field campaign in Fort McKay, Alberta, Canada, in January 2020. Its output was quantified in parallel by TD-CRDS and a Thermo 42i-Y NO-NOy CL instrument equipped with a Mo converter heated to $325^{\circ} \mathrm{C}$. This converter and the TD-CRDS quartz inlets were mounted on the roof of a trailer which housed the instruments and the HONO source. The TD-CRDS sampled at a flow rate of $\sim 1.2 \mathrm{slpm}$ per channel through $\sim 5 \mathrm{~cm}$ short, $300 \mu \mathrm{m}$ i.d. stainless steel flow restrictors placed inline after the heated quartz sections and before the Teflon filter assembly. The HONO source output was delivered via a $5 \mathrm{~m}$ long, $1 / 4^{\prime \prime}(0.64 \mathrm{~cm})$ o.d. and $3 / 16^{\prime \prime}(0.48 \mathrm{~cm})$ i.d. FEP Teflon tube to both instruments.

\section{Results}

\subsection{Development of a compact, high-purity HONO source}

The first design tested (source 1) produced an output of $\sim 38$ ppmv of HONO from a similar amount ( $>38$ ppmv) of 
$\mathrm{HCl}$ (Fig. S1a in the Supplement). This HONO mixing ratio is a factor of $\sim 10$ larger than the maximum recommended by Stutz et al. (2000) to avoid partial conversion of HONO to $\mathrm{NO}_{2}$ and $\mathrm{NO}$ via Reaction (R1). Consistently, the source output contained $\sim 4.0$ ppmv of $\mathrm{NO}_{2}$ (Fig. S1a) and an analogous amount of NO (Fig. S1b). Furthermore, the spectrum contained an absorption feature around $1808 \mathrm{~cm}^{-1}$, reproduced by $\sim 15.5$ ppmv of ClNO.

Nitrosyl chloride can be produced by reaction of HONO with gas-phase or wall-adsorbed $\mathrm{HCl}$ (Zhang et al., 1996; Wingen et al., 2000) or by reaction of two equivalents of $\mathrm{NO}_{2}$ with particulate-phase $\mathrm{Cl}^{-}$(Weis and Ewing, 1999), though the relatively low mixing ratios of $\mathrm{NO}_{2}$ in this system make this reaction less likely.

$$
\begin{aligned}
& \mathrm{HONO}_{(\mathrm{g})}+\mathrm{HCl}_{(\mathrm{g})} \rightarrow \mathrm{ClNO}_{(\mathrm{g})}+\mathrm{H}_{2} \mathrm{O}_{(\mathrm{g})} \\
& 2 \mathrm{NO}_{2(\mathrm{~g})}+\mathrm{Cl}^{-}(\mathrm{p}) \rightarrow \mathrm{ClNO}_{(\mathrm{g})}+\mathrm{NO}_{3}^{-}(\mathrm{p})
\end{aligned}
$$

The FTIR spectrum contained $\sim 50$ ppmv more $\mathrm{H}_{2} \mathrm{O}$ than the reference spectrum, i.e., more moisture than emitted by the permeation tube with $\mathrm{NaNO}_{2}$ bypassed. While this is consistent with ClNO production via $\mathrm{R} 5$, the $\mathrm{H}_{2} \mathrm{O}$ data are likely not meaningful since the $\mathrm{H}_{2} \mathrm{O}$ mixing ratios changed slowly over time (data not shown), possibly because of slow equilibration with the inner walls of the tubing and multi-pass cell and perhaps also because of water's presence in the FTIR optical path outside the multi-pass cell at a concentration that may have drifted.

Febo et al. (1995) reported lower production of $\mathrm{NO}_{x}$ by mechanically agitating the $\mathrm{NaNO}_{2}$ using a stir bar (to break up pockets of high [HONO]) and by heating the reaction vessel to $50^{\circ} \mathrm{C}$; these steps were incorporated into the second design (source 2). The FTIR spectrum of its output showed a consumption of $>\sim 42 \mathrm{ppmv} \mathrm{HCl}$ and production of $\sim 48 \mathrm{ppmv}$ of $\mathrm{HONO}, \sim 8.0 \mathrm{ppmv}$ of $\mathrm{NO}_{2}, \sim 6.5 \mathrm{ppmv}$ of $\mathrm{ClNO}, \sim 8$ ppmv of $\mathrm{NO}$, and $\sim 50$ ppmv of $\mathrm{H}_{2} \mathrm{O}$ (Fig. S2), an improvement over source 1 in terms of unwanted CINO production, but still inadequate.

A shorter $\mathrm{HCl}$ permeation tube was used in the third design, with the expectation that the lower $\mathrm{HCl}$ concentrations result in reduced generation of side products via R5 and R6. A sample FTIR spectrum of this source's output is shown in Fig. 2. With a freshly prepared $\mathrm{HCl}$ permeation tube and an estimated relative humidity in the round bottom flask of $\sim 25 \%,>\sim 2.5 \mathrm{ppmv} \mathrm{HCl}$ was consumed and $\sim 3.0 \mathrm{ppmv}$ of $\mathrm{HONO}$ was produced. The mixing ratios of undesired side products (i.e., $\mathrm{NO}, \mathrm{NO}_{2}, \mathrm{ClNO}$, and $\mathrm{HNO}_{3}$ ) were below their respective FTIR detection limits (Figs. 2, S3, and S4).

\subsection{Analysis of source output by TD-CRDS}

To better constrain the mole fractions of impurities, the source output was analysed by TD-CRDS. Figure 3 shows an example experiment. The TD-CRDS sampled scrubbed air before 21:38 UTC and after 21:58 UTC to determine the ring-down time constants in the absence of absorbers, $\tau_{0}$. In

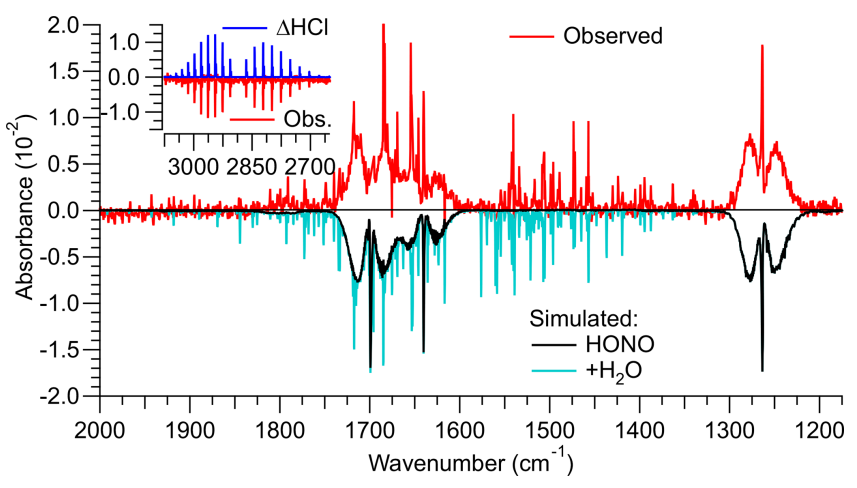

Figure 2. Infrared spectrum (shown in red colour) of a gas stream containing $\mathrm{HONO}$ generated by reaction of $\mathrm{HCl}_{(\mathrm{g})}$ with $\mathrm{NaNO}_{2}(\mathrm{~s})$ after the source was optimized. The reference spectrum was collected when $\mathrm{NaNO}_{2}$ was bypassed, i.e., contained $\mathrm{HCl}$. Literature spectra (Sharpe et al., 2004) were multiplied by the optical path length of $6.4 \mathrm{~m}$ and mixing ratios of the identified trace gases until they reproduced the observed spectrum. The optimized source delivered $3.0 \mathrm{ppmv}$ of $\mathrm{HONO}$ from $>2.5 \mathrm{ppmv}$ of $\mathrm{HCl}$. The spectrum also contained $\sim 4.0 \mathrm{ppmv}$ of $\mathrm{H}_{2} \mathrm{O}$. The $\mathrm{HCl}$ and $\mathrm{H}_{2} \mathrm{O}$ concentrations are underestimates of their true concentrations since their absorption lines are narrower than the resolution of the FTIR of $0.5 \mathrm{~cm}^{-1}$.

the time periods in between, varying amounts of the HONO output were sampled. There was little response other than in the $\mathrm{NO}_{y}$ channel, the only channel sensitive to HONO. Scatter plots of $\mathrm{NO}_{2}, \mathrm{NO}_{x}$, and $\mathrm{NO}_{x}+\Sigma \mathrm{PAN}+\Sigma \mathrm{AN}+$ $\mathrm{ClNO}+\mathrm{ClNO}_{2}$ ("HONO ref") against $\mathrm{NO}_{y}$ (Fig. 3, inserts) have slopes of $(1.29 \pm 0.06) \%,(1.54 \pm 0.06) \%$, and $(2.28 \pm 0.04) \%$, respectively, from which a source purity of $>97.3 \%$ was deduced.

When concentrations changed, the 90\%-10\% rise (and fall) times of the TD-CRDS were $<3 \mathrm{~s}$, a time constant identical to changes in $\mathrm{NO}_{x}$ concentration and indicating a "wellbehaved" inlet, i.e., the absence of inlet memory effects and fast equilibration with the inner walls of the inlet. The fast response contrasts with the rise (and fall) times of $\mathrm{HNO}_{3}$ of $>180 \mathrm{~s}$ (data not shown). Furthermore, the response in a channel sampling from an inlet heated to $600{ }^{\circ} \mathrm{C}$ without added $\mathrm{O}_{3}$ was the same as that of the $\mathrm{NO}_{2}$ channel (data not shown), consistent with the absence of $\mathrm{HNO}_{3}$ observed by FTIR spectroscopy (Fig. S4).

A quartz inlet temperature scan when the TD-CRDS was sampling a constant concentration of HONO is shown in Fig. 4. The experimental TD curve was reproduced by a fit to Eq. (2), which is based on Eq. (4) by Paul et al. (2009).

$$
\begin{aligned}
& {[\text { Observed }]_{\text {total }}=\left[\mathrm{NO}_{x}\right]} \\
& +[\mathrm{ClNO}]\left(1-e^{-A_{\mathrm{CINO}} \times e^{\frac{-E_{A, \mathrm{ClNO}}}{R T} \times \text { tres }}}\right) \\
& +[\mathrm{HONO}]\left(1-e^{-A_{\mathrm{HONO}} \times e^{\frac{-E_{A, \mathrm{HONO}}}{R T} \times t_{\mathrm{res}}}}\right)
\end{aligned}
$$




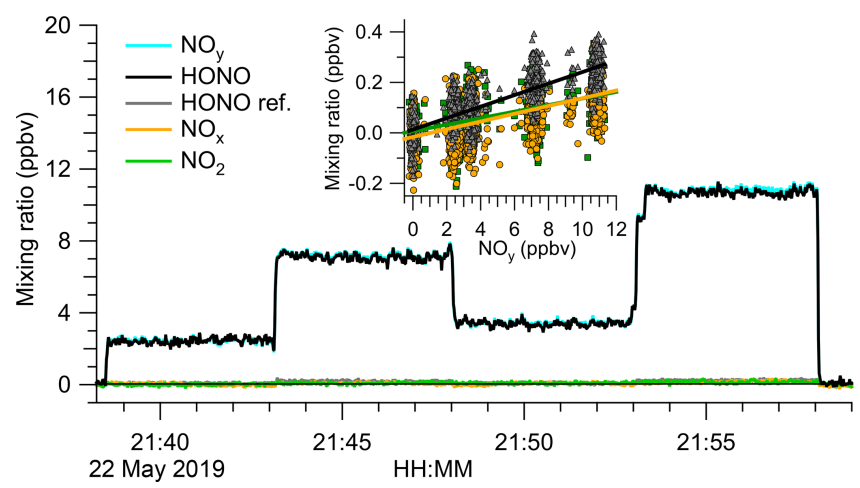

Figure 3. Analysis of the HONO source output by TD-CRDS. The TD-CRDS sampled scrubbed "zero" air before 21:38 UTC and after 21:58 UTC. The HONO source output was varied by incrementally opening (or closing) the bypass valve. The HONO mixing ratio was calculated by subtracting the response of the "HONO reference" from the $\mathrm{NO}_{y}$ channel. The insert shows scatter plots of $\mathrm{NO}_{2}, \mathrm{NO}_{x}$, and "HONO ref" against $\mathrm{NO}_{y}$. Slopes of $(1.29 \pm 0.06) \%$ for $\mathrm{NO}_{2}$ (points shown in green), $(1.54 \pm 0.06) \%$ for $\mathrm{NO}_{x}$ (data points shown in orange), and $(2.28 \pm 0.04) \%$ for "HONO ref" (points shown in grey) were determined, respectively.

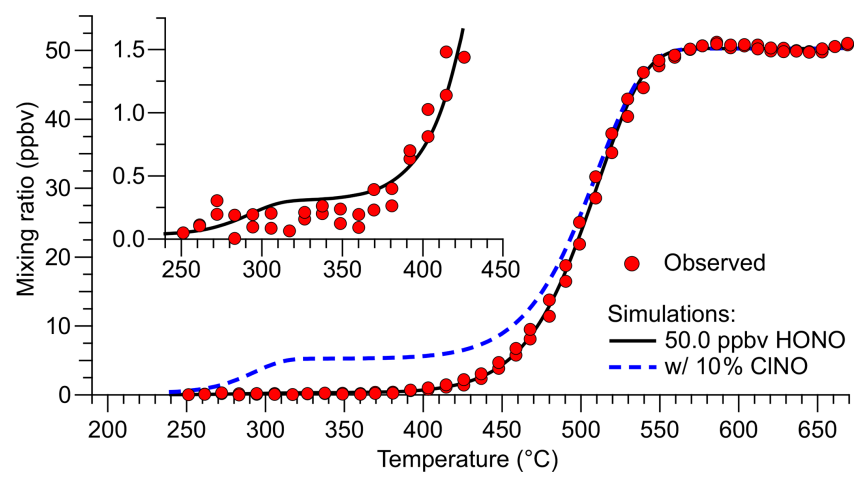

Figure 4. Inlet temperature scan when the TD-CRDS was sampling a constant concentration of HONO (data points shown in red). The TD profile was reproduced by a fit to Eq. (2) with mixing ratios of $(49.97 \pm 0.18),(0.27 \pm 0.34)$, and $(0.03 \pm 0.30) \mathrm{ppbv}$ for HONO, $\mathrm{ClNO}$, and $\mathrm{NO}_{x}$, respectively (black line). The blue dashed line shows the predicted TD curve of a hypothetical mixture containing 5.0 ppbv CINO and 45.0 ppbv HONO. The insert shows a close-up of the temperature region in which TD of CINO occurs.

Here, $A_{\mathrm{HONO}}$ and $E_{A, \mathrm{HONO}}$ are Arrhenius parameters for the TD of HONO taken from Tsang (1991), $A_{\mathrm{CINO}}$ and $E_{A, \mathrm{ClNO}}$ are from Baulch et al. (1981), and $t_{\text {res }}$ is the residence time of the gas in the converter at the converter set temperature $T$. A fit of Eq. (2) to the observation (superimposed as a black line in Fig. 4) using the Igor Pro software package (Wavemetrics) gave $t_{\text {res }}=(77.6 \pm 0.1) \mathrm{ms},\left[\mathrm{NO}_{x}\right]=(0.03 \pm$ $0.30)$ ppbv, $[\mathrm{ClNO}]=(0.27 \pm 0.34) \mathrm{ppbv}$, and $[\mathrm{HONO}]=$ $(49.97 \pm 0.18)$ ppbv, suggesting a source purity of $(99.4 \pm$ $0.9) \%$.
In our experience, the TD inflection points vary between TD-CRDS channels (and depend on sample flow rates), captured by the $t_{\text {res }}$ parameter that is specific to each channel. For the data shown in Fig. 4, HONO fully dissociates at a temperature of $\sim 570^{\circ} \mathrm{C}$, and the inflection point is at $\sim 500^{\circ} \mathrm{C}$. Nitrosyl chloride is predicted to fully dissociate at $\sim 330^{\circ} \mathrm{C}$ (inflection point at $\sim 288^{\circ} \mathrm{C}$ ), such that the temperature of $350^{\circ} \mathrm{C}$ chosen for the HONO ref channel (Fig. 3) is justified. The blue, dashed line superimposed in Fig. 4 shows a simulation of 5 ppbv $\mathrm{CINO}$ and 45 ppbv $\mathrm{HONO}$ to demonstrate the relative positions of the TD of CINO and HONO. We attempted to verify the CINO TD profile experimentally, but the unoptimized source's CINO outputs were not sufficiently stable, and those attempts were abandoned. Regardless, it is clear from Fig. 4 that the contribution of CINO to the total source output is negligible.

As can be seen from the insert in Fig. 4, HONO contributes a tiny amount to the TD-CRDS signal at $350{ }^{\circ} \mathrm{C}(\sim 4 \mathrm{pptv}$ in the simulation of $50 \mathrm{ppbv}$ HONO). This contribution may differ between quartz heaters and channels and could have been impacted by TD-CRDS using multiple parallel channels presented at the beginning of this section and in Fig. 3, leading to an overestimation of the total amount of impurities present in that experiment. The temperature scan data shown in Fig. 4, on the other hand, were collected using a single quartz heater and are thus more accurate.

\subsection{Source stability}

The source output gradually decreased over a timescale of weeks of continuous use, which was rationalized by the visible depletion of the $\mathrm{HCl}$ permeation tube. However, the source output remained stable and reproducible on shorter timescales. An example FTIR time series is shown in Fig. 5, which was acquired after 1 month of intermittent use. After a $1.5 \mathrm{~h}$ stabilization period, the source produced a stable output of $1.57 \mathrm{ppmv}$ of HONO (from > $1.0 \mathrm{ppmv}$ of $\mathrm{HCl}$ ) with a precision of \pm 35 ppbv.

\subsection{Source purity and day-to-day reproducibility}

The optimized source routinely delivered HONO in high purity (range $96.0 \%-98.7 \%$ ) as long as scrubbed, moisturecontaining room air was used as diluent gas (Table 2). When dry cylinder gas was used instead, the source output was stable but contained a larger amount of undesired side products; for example, on 25 July 2019, the output contained $4.6 \% \mathrm{NO}_{2}$ and $8.8 \% \mathrm{NO}+\mathrm{CINO}$ (Table 2). When used in the field, the performance was similar: with scrubbed air, the HONO purity was $98.5 \%$, whereas with dry cylinder gas, the purity was merely $81.3 \%$ (Table 2 and Fig. S5). 
Table 2. Summary of TD-CRDS analyses of the HONO source output. The RH of the diluent gas was in the range of $15 \%$ to $35 \%$, except for experiments conducted with cylinder gases which are shown below the line. The range of mixing ratios stated is for output after dilution. The stated errors are from regression analyses of plots of $\mathrm{NO}_{2}, \mathrm{NO}_{x}$, or $\mathrm{NO}_{x}+\mathrm{ClNO}$ vs. $\mathrm{NO}_{y}$ and are at the $1 \sigma$ level. $\mathrm{n} / \mathrm{d}$ : not determined.

\begin{tabular}{lllrrrrr}
\hline Date & Setting & Diluent gas & $\begin{array}{r}\text { Range } \\
(\mathrm{ppbv})\end{array}$ & $\begin{array}{r}\mathrm{HONO} \\
(\%)\end{array}$ & $\begin{array}{r}\mathrm{NO}_{2} \\
(\%)\end{array}$ & $\begin{array}{r}\mathrm{NO}_{x} \\
(\%)\end{array}$ & $\begin{array}{r}\mathrm{NO}_{x}+\mathrm{ClNO} \\
(\%)\end{array}$ \\
\hline 16 January 2019 & Lab & Scrubbed air & $0-140$ & $\mathrm{a} 97.2 \pm 0.1$ & $\mathrm{n} / \mathrm{d}$ & $2.80 \pm 0.07$ & $\mathrm{n} / \mathrm{d}$ \\
3 May 2019 & Lab & Scrubbed air & $0-7$ & $96.0 \pm 0.2$ & $1.9 \pm 0.2$ & $4.0 \pm 0.2$ & $(4.0 \pm 0.2)^{\mathrm{b}}$ \\
6 May 2019 & Lab & Scrubbed air & $0-93$ & $96.4 \pm 0.4$ & $1.9 \pm 0.4$ & $3.6 \pm 0.4$ & $(3.6 \pm 0.4)^{\mathrm{b}}$ \\
10 May 2019 & Lab & Scrubbed air & $0-21$ & $\mathrm{a} 97.6 \pm 0.1$ & $1.10 \pm 0.03$ & $2.40 \pm 0.05$ & $\mathrm{n} / \mathrm{d}$ \\
17 May 2019 & Lab & Scrubbed air & $0-38$ & $98.7 \pm 0.1$ & $0.01 \pm 0.02$ & $0.92 \pm 0.01$ & $1.25 \pm 0.01$ \\
22 May 2019 & Lab & Scrubbed air & $0-14$ & $97.7 \pm 0.1$ & $1.29 \pm 0.06$ & $1.54 \pm 0.06$ & $2.28 \pm 0.04$ \\
17 January 2020 & Field & Scrubbed air & $0-80$ & $98.5 \pm 0.1$ & $1.00 \pm 0.05$ & $1.50 \pm 0.08$ & $(1.50 \pm 0.08)^{\mathrm{b}}$ \\
19 March 2020 & Lab & Scrubbed air & $0-320$ & ${ }^{9} 98.72 \pm 0.01$ & $\mathrm{n} / \mathrm{d}$ & $1.28 \pm 0.01$ & $\mathrm{n} / \mathrm{d}$ \\
\hline 25 July 2019 & Lab & Cylinder $\mathrm{O}_{2}$ & $0-95$ & $86.60 \pm 0.02$ & $4.60 \pm 0.03$ & $\mathrm{n} / \mathrm{d}$ & $13.4 \pm 0.02$ \\
30 January 2020 & Field & Cylinder $\mathrm{N}_{2}$ & $0-50$ & $81.3 \pm 0.1$ & $5.90 \pm 0.09$ & $\mathrm{n} / \mathrm{d}$ & $18.7 \pm 0.1$ \\
\hline
\end{tabular}

${ }^{a}$ Upper limit. ${ }^{b}$ The TD-CRDS quartz inlet temperature was ramped between 300 and $600^{\circ} \mathrm{C}$; the TD-CRDS mixing ratios at an inlet temperature of $300^{\circ} \mathrm{C}$ matched the $\mathrm{NO}_{x}$ mixing ratios observed with the room temperature inlet, indicating the absence of CINO.

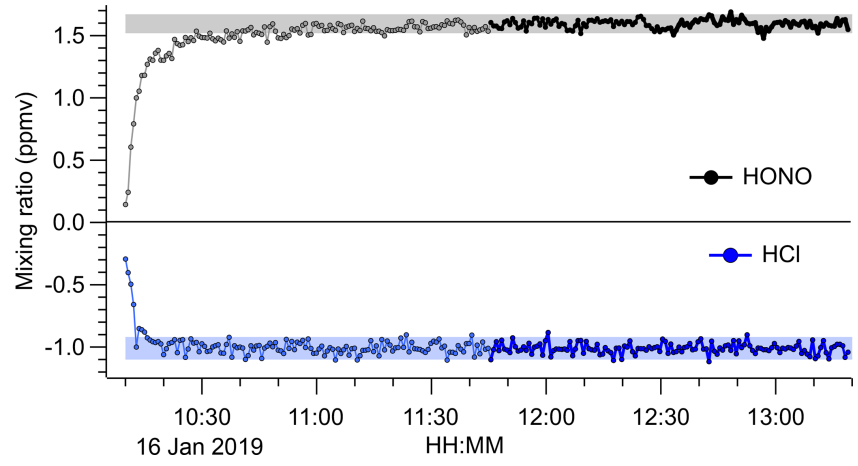

Figure 5. Time series of $\mathrm{HONO}$ and $\mathrm{HCl}$ mixing ratios derived from FTIR analysis of the undiluted HONO source output. The $\mathrm{NaNO}_{2}$ was placed in line at 10:10 UTC. Data acquired during the initial period are shown in light grey colour. The shaded areas represent the average $\pm 2 \sigma$ after the source output was judged to have stabilized (after 11:45 UTC; data points shown in black colour). The $1 \sigma$ precision of the HONO data was $\pm 35 \mathrm{ppbv}$ and that of the $\mathrm{HCl}$ data was \pm 42 ppbv. The $\mathrm{HCl}$ mixing ratios are an underestimate because the widths of their absorption lines are less than the FTIR's resolution of $0.5 \mathrm{~cm}^{-1}$.

\section{Discussion}

In this work, a small-footprint, portable, stable, rapidly tuneable, and high-purity ( $>97 \%$ on average) HONO source has been described. The source achieves compactness by using a diffusion tube containing $0.35 \mathrm{~mL}$ concentrated $\mathrm{HCl}$ rather than a $1 \mathrm{~L} \mathrm{HCl}$ bath. The latter is a considerable hazard since an $\mathrm{HCl}$ spill can cause severe burns of skin or permanent eye damage, and hydrochloric acid vapours are toxic to inhale. Hence, smaller volumes are preferred when deploying to the field. The source stabilizes within a time frame of $1.5 \mathrm{~h}$ (Fig. 5), which is fast compared to, for example, the $10 \mathrm{~d}$ stabilization period reported by Roberts et al. (2010). The source output is also rapidly tuneable (Fig. 3), which allows expedient generation of calibration plots. These properties make it a useful setup for in-field instrument calibrations.

The combination of FTIR and TD-CRDS provided a unique and powerful tool set to analyse the purity of the source's output. This work has shown that HONO sources based on Reaction (R4) can generate $\mathrm{NO}, \mathrm{NO}_{2}$, and $\mathrm{ClNO}$ as by-products via Reactions (R1) and (R5). Febo et al. (1995) and Roberts et al. (2010) have presented HONO sources based on R4 and demonstrated stoichiometric conversion of $\mathrm{HCl}$ to $\mathrm{HONO}$. The results in this work suggest that devices relying solely on loss of $\mathrm{HCl}$ for calibration of $\mathrm{HONO}$ output should be used with caution as co-production of NO, $\mathrm{NO}_{2}$, and ClNO is a real possibility. In our setup, formation of $\mathrm{ClNO}$ could be avoided by keeping the $\mathrm{HCl}$ concentration low (i.e., $<4$ ppmv), which puts an important constraint on sources generating HONO by Reaction (R4). With this in mind, it is instructive to scrutinize the earlier work in regard to side product formation. It has generally been noted that the presence of moisture is needed to ensure a high HONO output. We suggest that water is needed in part because CINO is prone to hydrolysis (Karlsson and Ljungstrom, 1996), such that the product distribution is shifted towards HONO.

$\mathrm{ClNO}_{(\mathrm{g})}+\mathrm{H}_{2} \mathrm{O}_{(\mathrm{g})} \rightarrow \mathrm{HONO}_{(\mathrm{g})}+\mathrm{HCl}_{(\mathrm{g})}$

Roberts et al. (2010) observed no CINO production, likely because they kept their concentrations relatively low $(<900 \mathrm{ppbv})$ and humidified their gas streams, though they appear to be just below the threshold of possible CINO production. Perez et al. (2007), on the other hand, observed CINO but did not disclose details as to how they operated their source, i.e., whether they worked under trace conditions and with humidified gases, though it is likely that either or 
both conditions were not met. Schiller et al. (2001) bubbled $\mathrm{N}_{2}$ through liquid $\mathrm{HCl}$ and would have certainly achieved a high enough $\mathrm{HCl}$ concentration to generate $\mathrm{ClNO}$ with their setup. However, they reported achieving higher HONO output in the presence of moisture. Hydrolysis of CINO (Reaction R7) may be a (partial) explanation why the presence of $\mathrm{H}_{2} \mathrm{O}$ improved the output of their HONO.

The present $\mathrm{HONO}$ source has a large dynamic range $(0-$ 1 ppmv), well above the HONO concentrations found in ambient air. For field calibrations in future, it may be desirable to construct a permeation tube with lower $\mathrm{HCl}$ output, for example by lowering the $\mathrm{HCl}$ concentration in the permeation tube.

Data availability. The data used in this study are available from the corresponding author upon request (hosthoff@ucalgary.ca).

Supplement. The supplement related to this article is available online at: https://doi.org/10.5194/amt-13-4159-2020-supplement.

Author contributions. NJG and HDO designed the experiments and carried them out.

Competing interests. The authors declare that they have no conflict of interest.

Acknowledgements. Nicholas J. Gingerysty is grateful for an Alberta Graduate Excellence Scholarship (AGES).

Financial support. This research has been supported by the Natural Sciences and Engineering Research Council of Canada (NSERC, grant no. RGPIN/03849-2016) and Environment and Climate Change Canada (project no. GCXE19S036).

Review statement. This paper was edited by Andreas Hofzumahaus and reviewed by two anonymous referees.

\section{References}

Baulch, D. L., Duxbury, J., Grant, S. J., and Montague, D. C.: Evaluated kinetic data for high-temperature reactions, vol. 4: Homogeneous gas-phase reactions of halogen-containing and cyanidecontaining species, J. Phys. Chem. Ref. Data, 10, Supplement 1, 1-721, 1981.

Braman, R. S. and De la Cantera, M. A.: Sublimation sources for nitrous acid and other nitrogen compounds in air, Anal. Chem., 58, 1533-1537, https://doi.org/10.1021/ac00298a059, 1986.
Brust, A. S., Becker, K. H., Kleffmann, J., and Wiesen, P.: UV absorption cross sections of nitrous acid, Atmos. Environ., 34, 1319, https://doi.org/10.1016/S1352-2310(99)00322-2, 2000.

Cox, R. A.: The photolysis of gaseous nitrous acid, J. Photochem., 3, 175-188, https://doi.org/10.1016/0047-2670(74)80018-3, 1974.

Cox, R. A. and Derwent, R. G.: The ultra-violet absorption spectrum of gaseous nitrous acid, J. Photochem., 6, 23-34, https://doi.org/10.1016/0047-2670(76)87004-9, 1976.

Crilley, L. R., Kramer, L. J., Ouyang, B., Duan, J., Zhang, W., Tong, S., Ge, M., Tang, K., Qin, M., Xie, P., Shaw, M. D., Lewis, A. C., Mehra, A., Bannan, T. J., Worrall, S. D., Priestley, M., Bacak, A., Coe, H., Allan, J., Percival, C. J., Popoola, O. A. M., Jones, R. L., and Bloss, W. J.: Intercomparison of nitrous acid (HONO) measurement techniques in a megacity (Beijing), Atmos. Meas. Tech., 12, 6449-6463, https://doi.org/10.5194/amt12-6449-2019, 2019.

Febo, A., Perrino, C., Gherardi, M., and Sparapani, R.: Evaluation of a High-Purity and High-Stability Continuous Generation System for Nitrous Acid, Environm. Sci. Technol., 29, 2390-2395, https://doi.org/10.1021/es00009a035, 1995.

Fuchs, H., Dubé, W. P., Lerner, B. M., Wagner, N. L., Williams, E. J., and Brown, S. S.: A Sensitive and Versatile Detector for Atmospheric $\mathrm{NO}_{2}$ and $\mathrm{NO}_{x}$ Based on Blue Diode Laser Cavity Ring-Down Spectroscopy, Environm. Sci. Technol., 43, 78317836, https://doi.org/10.1021/es902067h, 2009.

Jordan, N. and Osthoff, H. D.: Quantification of nitrous acid (HONO) and nitrogen dioxide $\left(\mathrm{NO}_{2}\right)$ in ambient air by broadband cavity-enhanced absorption spectroscopy (IBBCEAS) between 361 and $388 \mathrm{~nm}$, Atmos. Meas. Tech., 13, 273-285, https://doi.org/10.5194/amt-13-273-2020, 2020.

Karlsson, R. S. and Ljungstrom, E. B.: Laboratory study of CINO: Hydrolysis, Environm. Sci. Technol., 30, 2008-2013, https://doi.org/10.1021/es950801f, 1996.

King, G. W. and Moule, D.: The ultraviolet absorption spectrum of nitrous acid in the vapor state, Can. J. Chem., 40, 2057-2065, https://doi.org/10.1139/v62-316, 1962.

Odame-Ankrah, C. A.: Improved detection instrument for nitrogen oxide species, $\mathrm{PhD}$, Chemistry, University of Calgary, Calgary, Canada, https://doi.org/10.5072/PRISM/26475, 2015.

Paul, D., Furgeson, A., and Osthoff, H. D.: Measurements of total peroxy and alkyl nitrate abundances in laboratorygenerated gas samples by thermal dissociation cavity ring-down spectroscopy, Rev. Sci. Instrum., 80, 114101, https://doi.org/10.1063/1.3258204, 2009.

Paul, D. and Osthoff, H. D.: Absolute Measurements of Total Peroxy Nitrate Mixing Ratios by Thermal Dissociation Blue Diode Laser Cavity Ring-Down Spectroscopy, Anal. Chem., 82, 66956703, https://doi.org/10.1021/ac101441z, 2010.

Perez, I. M., Wooldridge, P. J., and Cohen, R. C.: Laboratory evaluation of a novel thermal dissociation chemiluminescence method for in situ detection of nitrous acid, Atmos. Environm., 41, 3993 4001, https://doi.org/10.1016/j.atmosenv.2007.01.060, 2007.

Reed, C., Brumby, C. A., Crilley, L. R., Kramer, L. J., Bloss, W. J., Seakins, P. W., Lee, J. D., and Carpenter, L. J.: HONO measurement by differential photolysis, Atmos. Meas. Tech., 9, 24832495, https://doi.org/10.5194/amt-9-2483-2016, 2016.

Ren, X., Gao, H., Zhou, X., Crounse, J. D., Wennberg, P. O., Browne, E. C., LaFranchi, B. W., Cohen, R. C., McKay, M., 
Goldstein, A. H., and Mao, J.: Measurement of atmospheric nitrous acid at Bodgett Forest during BEARPEX2007, Atmos. Chem. Phys., 10, 6283-6294, https://doi.org/10.5194/acp-106283-2010, 2010.

Roberts, J. M., Veres, P. R., Warneke, C., Neuman, J. A., Washenfelder, R. A., Brown, S. S., Baasandorj, M., Burkholder, J. B., Burling, I. R., Johnson, T. J., Yokelson, R. J., and de Gouw, J.: Measurement of HONO, HNCO, and other inorganic acids by negative-ion proton-transfer chemical-ionization mass spectrometry (NI-PT-CIMS): application to biomass burning emissions, Atmos. Meas. Tech., 3, 981-990, https://doi.org/10.5194/amt-3981-2010, 2010.

Schiller, C. L., Locquiao, S., Johnson, T. J., and Harris, G. W.: Atmospheric measurements of HONO by tunable diode laser absorption spectroscopy, J. Atmos. Chem., 40, 275-293, https://doi.org/10.1023/A:1012264601306, 2001.

Sharpe, S. W., Johnson, T. J., Sams, R. L., Chu, P. M., Rhoderick, G. C., and Johnson, P. A.: Gas-phase databases for quantitative infrared spectroscopy, Appl. Spectrosc., 58, 1452-1461, 2004.

Stockwell, W. R. and Calvert, J. G.: The near ultraviolet absorption spectrum of gaseous HONO and $\mathrm{N}_{2} \mathrm{O}_{3}$, J. Photochem., 8, 193203, https://doi.org/10.1016/0047-2670(78)80019-7, 1978.

Stutz, J., Kim, E. S., Platt, U., Bruno, P., Perrino, C., and Febo, A.: UV-visible absorption cross sections of nitrous acid, J. Geophys. Res., 105, 14585-14592, https://doi.org/10.1029/2000JD900003, 2000.

Taha, Y. M., Odame-Ankrah, C. A., and Osthoff, H. D.: Real-time vapor detection of nitroaromatic explosives by catalytic thermal dissociation blue diode laser cavity ring-down spectroscopy, Chem. Phys. Lett., 582, 15-20, https://doi.org/10.1016/j.cplett.2013.07.040, 2013.
Taira, M. and Kanda, Y.: Continuous generation system for lowconcentration gaseous nitrous acid, Anal. Chem., 62, 630-633, https://doi.org/10.1021/ac00205a018, 1990.

Tsang, W. and Herron, J. T.: Chemical Kinetic Data Base for Propellant Combustion I. Reactions Involving $\mathrm{NO}, \mathrm{NO}_{2}, \mathrm{HNO}$, $\mathrm{HNO}_{2}, \mathrm{HCN}$ and $\mathrm{N}_{2} \mathrm{O}$, J. Phys. Chem. Ref. Data, 20, 609-663, https://doi.org/10.1063/1.555890, 1991.

Weis, D. D. and Ewing, G. E.: The Reaction of Nitrogen Dioxide with Sea Salt Aerosol, J. Phys. Chem. A, 103, 4865-4873, https://doi.org/10.1021/jp984488q, 1999.

Wild, R. J., Edwards, P. M., Dube, W. P., Baumann, K., Edgerton, E. S., Quinn, P. K., Roberts, J. M., Rollins, A. W., Veres, P. R., Warneke, C., Williams, E. J., Yuan, B., and Brown, S. S.: A Measurement of Total Reactive Nitrogen, $\mathrm{NO}_{y}$, together with $\mathrm{NO}_{2}$, $\mathrm{NO}$, and $\mathrm{O}_{3}$ via Cavity Ring-down Spectroscopy, Environm. Sci. Technol., 48, 9609-9615, https://doi.org/10.1021/es501896w, 2014.

Wingen, L. M., Barney, W. S., Lakin, M. J., Brauers, T., and Finlayson-Pitts, B. J.: A unique method for laboratory quantification of gaseous nitrous acid (HONO) using the reaction $\mathrm{HONO}+\mathrm{HCl} \rightarrow \mathrm{ClNO}+\mathrm{H}_{2} \mathrm{O}$, J. Phys. Chem. A, 104, 329-335, https://doi.org/10.1021/jp992890e, 2000.

Zhang, R., Leu, M.-T., and Keyser, L. F.: Heterogeneous Chemistry of HONO on Liquid Sulfuric Acid:? A New Mechanism of Chlorine Activation on Stratospheric Sulfate Aerosols, J. Phys. Chem A, 100, 339-345, https://doi.org/10.1021/jp952060a, 1996. 